\title{
Analysis of the main criteria used in expert handwriting analysis of signatures
}

Hospital Getúlio Vargas, Recife, Pernambuco, Brasil.

Universidade de Pernambuco - UPE, Escola Politécnica, Programa de Pós-graduaçao em Engenharia da Computação - PPGEC, Recife, Pernambuco, Brasil.

Faculdade IDE - Instituto de Desenvolvimento Educacional, Recife, Pernambuco, Brasil.

Serviço Social da Industria - SESI, Recife, Pernambuco, Brasil.

Universidade de Pernambuco - UPE, Escola Politécnica, Recife, Penambuco, Brasil.

${ }^{6}$. Universidade Federal de Pernambuco UFPE, Curso de Fonoaudiologia, Programa de Mestrado em Saúde da Comunicação Humana, Recife, Pernambuco, Brasil.

Universidade de Pernambuco - UPE, Programa de Mestrado em Perícias Forenses, Recife, Pernambuco, Brasil.

Study developed at Universidade de Pernambuco - UPE, Recife, Pernambuco, Brazil.

Research support source: Coordenacão de Aperfeiçoamento de Pessoal de Nível Superior - CAPES, Brasil.

Conflict of interests: Nonexistent

\section{(c) (i)}

Received on: April 2, 2021 Accepted on: September 27, 2021

Corresponding address: Ana Patrícia Carvalho de Melo

Rua Baltazar Passos, 310/201 - Boa Viagem CEP 51130-290 - Recife, Pernambuco, Brasil

E-mail: patfono2@hotmail.com

\author{
Ana Patrícia Carvalho de Melo ${ }^{1}$ \\ https://orcid.org/0000-0002-0972-1934 \\ Byron Leite Dantas Bezerra ${ }^{2}$ \\ https://orcid.org/0000-0002-8327-9734 \\ Celso Antônio Marcionilo Lopes Júnior² \\ https://orcid.org/0000-0003-1356-5759 \\ Fernanda Gabrielle Andrade Lima ${ }^{3}$ \\ https://orcid.org/0000-0003-4673-6366 \\ Luciana Vaz de Oliveira Lucena ${ }^{4}$ \\ https://orcid.org/0000-0002-4635-0431 \\ Murilo Campanhol Stodolni ${ }^{5}$ \\ https://orcid.org/0000-0002-0875-2907
}

Denise Costa Meneses ${ }^{6}$ https://orcid.org/0000-0002-2008-4091

Karina Paes Advíncula ${ }^{6,7}$ https://orcid.org/0000-0002-1314-6100

\section{ABSTRACT}

Purpose: to analyze the criteria most used by experts in the handwriting analysis report.

Methods: a descriptive, quantitative, inferential, and cross-sectional study, with statistical analysis of the results obtained with a form administered to the experts. The statistical calculations were made with $\mathrm{R}$ language, version 4.0.1, with statistical significance set at $5 \%$.

Results: the absolute frequency analysis indicated a greater occurrence of the use of initial and final pen strokes and handwriting progress, with a relative frequency above $70 \%$. A detailed evaluation with univariate analysis showed that these criteria are not relevant to correct conclusions in the expert analysis report. It also pointed out that morphology is a relevant criterion to infer whether an evaluation is correct. The data showed that initial pen stroke, inclination, dynamism, and evolution, when observed in terms of multivariate modeling, were not significant, indicating that subjectivity is essential for the experts to make correct analyses.

Conclusion: the most reported expert handwriting analysis criteria in relation to the experts' correct analyses were not statistically relevant for the development of the analysis reports.

Keywords: Expert Testimony; Handwriting; Speech, Language and Hearing Sciences 


\section{INTRODUCTION}

In an specialized examination, the types of handwriting are analyzed by experts, who use graphometry to analyze full texts and signatures and identify their authors.

The comparative analyses between samples point out similarities and differences, making it possible to recognize the author of the handwriting.

The following types of signatures are the most common ones in handwriting reports, which describe the focus and form of analysis: simplified signatures; signatures with overlapping traces; legible elaborate signatures; legible non-elaborate signatures; illegible signatures - which is the category where stylized signatures are included ${ }^{1}$.

There are many limitations and difficulties in handwriting analyses to identify the author of a rather illegible signature. Therefore, the criteria identified in handwriting movement analyses must be detailed and specific to each situation.

Analyses between handwritings are not restricted confrontation processes; they require in-depth dedication, which encompasses all information available, including the handwriting habits of those involved ${ }^{2}$.

Expert handwriting analysis involves the observation of a significant combination of unique written constructions that can be either convergent or divergent when compared to a pattern in expert analysis ${ }^{3}$.

The study of the writing habits in graphometry requires not only the comparison between two signatures but also a detailed analysis of the material and information contained in them².

The individual characteristics are the most important components, which can add or omit some handwriting traces $^{4,5}$.

Gorziza $(2017)^{6}$ reports that the writing characteristics most frequently changed in frauded signatures are the format of capital and lowercase letters; the size of the signature, in which the frauded one is totally or partly longer or shorter; the forms and/or positions how a pen stroke begins and ends; change or suppression of symbols or characters, including dots, accent marks, additional traces, letter prolongations, and abstract parts of the signature, with specific construction methods; and changes on how the pen is lifted from the paper in writing, as in some frauds the pen is lifted more often than in the original signature, while in other it is lifted less often. These characteristics can also be observed when attempting to fraud stylized signatures.
Besides these technical criteria, other aspects must be considered, such as generic elements (which the writer can change at any moment) and genetic elements, handwriting morphology, and graphic familiarity (which cannot be changed because they are intrinsic to the writer's handwriting). All these aspects, when examined together, lead the handwriting expert analyst to solve a case that was entrusted to them and detail them in the forensic analysis report - a unique and individualized piece that is included as evidence in a trial ${ }^{7}$.

Law 13.105 - under article 156, which provides on essential norms and applicability of trial norms provides that the expert must be indicated from one of the legally qualified professionals and that the courts are responsible for assessing and reassessing them to maintain their registries in the jurisdiction. Hence, the experts interested in such work must have professional training and updated knowledge and experience ${ }^{8}$. The law does not specify the required technical training, minimum course load, and prerequisites to become an expert.

The Conselho Federal de Fonoaudiologia (Federal Speech-Language-Hearing Council), in its Resolution no. 584, presents to the public a new specialization in speech-language-hearing sciences: that of an expert speech-language-hearing analyst, including graphometry (the analysis of the writer's handwriting) in their scope of knowledge ${ }^{9}$. Speech-language-hearing is one of the health sciences that has now recognized professional expert analysts, pointing out their analysis expertise and delimitations.

Hence, expert speech-language-hearing analysts and other professionals who work with graphometry have the tough task of stating the authenticity or inauthenticity of questioned handwritten material. As they do so, they must be sure of the results of the expert analysis, as their report will be an important tool helping the judges' sentences.

The experts can use many criteria. Using and selecting them is a spontaneous decision, as there are no obligatory recommendations regarding their use and choice in expert analysis.

Hence, the main criteria used in graphometry to analyze stylized signatures must be identified to recognize the most frequent handwriting patterns, thus making expert graphometry easier and improving its quality. 
The objective of this study was to analyze the criteria most used by experts, observing whether they are relevant to a correct judgment in expert graphometry.

\section{METHODS}

This study was approved by the Research Ethics Committee of the Universidade de Pernambuco (University of Pernambuco - UPE), Brazil, under evaluation report number 3.822.907.

The research was developed in Brazilian territory. A total of 37 graphometry experts who work in official (statutory work) and extraofficial settings (non-statutory work) participated in the study. Altogether, they analyzed 151 signatures. The experts were identified through active search in the websites of the Secretaria Nacional de Segurança Pública/Ministério da Justiça (National Department of Public Security/Ministry of Justice), Cadastro Nacional de Peritos (National Expert Registry), and the Conselho Nacional de Peritos Judiciais (National Council of Forensic Experts). After finding the experts, they were contacted and invited via WhatsApp, Instagram, and e-mail to participate in the research. They were asked to access a website developed in partnership with Computer Engineering postgraduate students at Universidade de Pernambuco. The signatures images, obtained from real cases, originated from the GPDS database ${ }^{10}$ (Appendix 1). For the selection criteria, the signatures to be analyzed had to be from this database. They were collected in white tracing paper and photographed; hence, they were extracted and still maintained the same resolution characteristics in grayscale, which is necessary for digital analysis.

When the experts accessed the website, they indicated their agreement to participate, virtually signing the informed consent form (Appendix 2). Then, they were directed to the research form, where they analyzed pairs of signatures to find the handwriting identity. The experts were instructed on how to proceed with the analysis - they had to compare the signatures, based on the literature, without definitions or concepts, except for the ones listed in the form, which consisted of basic knowledge to analyze the signatures. They were then instructed to check the criteria they used in each analysis (Appendix 3). Ten pairs of signature images were made available, and they were asked to analyze at least five of them. Hence, for each pair of signatures, the expert would have to use their analysis expertise and check which of the criteria made available in the form they used to reach a result. They followed the instructions on the website (which asked for a result in each pair of signatures) and informed whether they belonged to the same handwriting. After providing the answer, they were expected to point out which criteria they used in the analysis to reach a conclusion. The questionnaire was developed based on technical references for handwriting analysis, based on the existing literature ${ }^{11-13}$, which were included in the instructions to the participants.

The analyses were initially calculated to research the relative and absolute frequencies of the variables being studied and obtain a general profile.

The two-step conditional logistic regression was applied to identify the criteria that most led to correct analyses on the part of the experts.

The conditional logistic regression is an extension of the usual logistic regression, useful when data collection is stratified. This scenario denies the supposition of statistical independence of the sample units, which must be met in usual logistic regression. If this is not observed, the parameter estimates are biased, and their inference is compromised ${ }^{14}$.

The first stage consisted of computing the odds ratios in univariate identification, analyzing both the individual criteria and the relationship between them and the experts' correct analyses. In the second stage, a multivariate conditional logistic regression model was estimated, analyzing the set of criteria that stood out in the univariate analysis, to observe the relationships between promising variables (i.e., with odds ratio p-value below 0.2 in the previous stage) and the experts' correct analyses. The multivariate analysis is used to find a multifactorial pattern of correct analyses.

For this study, as each evaluator could analyze up to 10 images, the extracts were considered as the evaluators themselves. Thus, there are 37 different size extracts, as not all evaluators analyzed the 10 images. The digital signatures may have posed a difficulty to some experts given the lack of familiarity with this type of presentation. This may have decreased the number of criteria checked in the form.

The statistical significance was set at $5 \%$. All the calculations were made in $\mathrm{R}$ language, version 4.0.1.

It was not the objective of this paper to compare demographic areas and relationships regarding the participation of official and extraofficial experts. These data may be approached in future research. 


\section{RESULTS}

The (I) initial pen stroke, (II) final pen stroke, and (III) writing progress had a relative frequency above $70 \%$, as seen in Table 1.
Initial pen stroke is the beginning of the writing movement, the final pen stroke is the end of the writing movement, and writing progress verifies the identity, quantity, and regularity of moments (traces of a movement) and writing spacings ${ }^{9}$.

Table 1. Absolute and relative frequencies of the variables studied

\begin{tabular}{|c|c|c|c|}
\hline VARIABLE & CATEGORY & $N=151$ & $\%$ \\
\hline \multirow{2}{*}{ Responded correctly } & No & 54 & 35.8 \\
\hline & Yes & 97 & 64.2 \\
\hline \multirow{2}{*}{ Time to vote (in levels) } & Less than 30 min. & 145 & 96.0 \\
\hline & 30 or more min. & 6 & 4.0 \\
\hline \multirow{2}{*}{ Writing progress } & No & 45 & 29.8 \\
\hline & Yes & 106 & 70.2 \\
\hline \multirow{2}{*}{ Connections } & No & 74 & 49.0 \\
\hline & Yes & 77 & 51.0 \\
\hline \multirow{2}{*}{ Initial pen stroke } & No & 33 & 21.9 \\
\hline & Yes & 118 & 78.1 \\
\hline \multirow{2}{*}{ Final pen stroke } & No & 44 & 29.1 \\
\hline & Yes & 107 & 70.9 \\
\hline \multirow{2}{*}{ Positioning } & No & 112 & 74.2 \\
\hline & Yes & 39 & 25.8 \\
\hline \multirow{2}{*}{ Alignment } & No & 99 & 65.6 \\
\hline & Yes & 52 & 34.4 \\
\hline \multirow{2}{*}{ Angular values } & No & 72 & 47.7 \\
\hline & Yes & 79 & 52.3 \\
\hline \multirow{2}{*}{ Curvilinear values } & No & 78 & 51.7 \\
\hline & Yes & 73 & 48.3 \\
\hline \multirow{2}{*}{ Allographs } & No & 119 & 78.8 \\
\hline & Yes & 32 & 21.2 \\
\hline \multirow{2}{*}{ Construction method } & No & 98 & 64.9 \\
\hline & Yes & 53 & 35.1 \\
\hline \multirow{2}{*}{ Punctuations and diacritics } & No & 136 & 90.1 \\
\hline & Yes & 15 & 9.9 \\
\hline \multirow{2}{*}{ Inclination } & No & 85 & 56.3 \\
\hline & Yes & 66 & 43.7 \\
\hline \multirow{2}{*}{ Dynamism or evolution } & No & 80 & 53.0 \\
\hline & Yes & 71 & 47.0 \\
\hline \multirow{2}{*}{ Pressure } & No & 99 & 65.6 \\
\hline & Yes & 52 & 34.4 \\
\hline \multirow{2}{*}{ Writing rhythm } & No & 93 & 61.6 \\
\hline & Yes & 58 & 38.4 \\
\hline \multirow{2}{*}{ Line behavior } & No & 139 & 92.1 \\
\hline & Yes & 12 & 7.9 \\
\hline \multirow{2}{*}{ Base behavior } & No & 125 & 82.8 \\
\hline & Yes & 26 & 17.2 \\
\hline \multirow{2}{*}{ Degree of skill } & No & 109 & 72.2 \\
\hline & Yes & 42 & 27.8 \\
\hline \multirow{2}{*}{ Pulse tendency } & No & 88 & 58.3 \\
\hline & Yes & 63 & 41.7 \\
\hline
\end{tabular}




\begin{tabular}{lccc}
\hline VARIABLE & CATEGORY & $\mathbf{N}=\mathbf{1 5 1}$ & \% \\
\hline Handwriting moments & No & 97 & 64.2 \\
\multirow{2}{*}{ Variability } & Yes & 54 & 35.8 \\
& No & 129 & 85.4 \\
Speed & Yes & 22 & 14.6 \\
& No & 82 & 54.3 \\
Spacings & Yes & 69 & 45.7 \\
& No & 95 & 62.9 \\
Verbal limiting lines & Yes & 56 & 37.1 \\
& No & 140 & 92.7 \\
Caliber and proportions & Yes & 11 & 7.3 \\
& No & 93 & 61.6 \\
Morphology & Yes & 58 & 38.4 \\
\multirow{2}{*}{ Nature } & No & 112 & 74.2 \\
& Yes & 39 & 25.8 \\
\hline
\end{tabular}

The initial pen stroke is analyzed observing the manner how the writing instrument first touches the paper. Likewise, the final pen stroke analyzes how the writing instrument last touches the paper.

When analyzing the writing moment, the expert observes how that handwriting develops as the writing instrument is in contact with the paper, until the contact is ended or paused. Then, they also observe the spacings in the survey - the interlinear ones are found in unlined paper, the interword spaces are found by measuring the distance in between words, and the intercharacter is the distance in between letters.

These criteria occurred in higher percentages among the experts who participated in this experiment. As seen in the technical definition of these criteria, they enable an end-to-end analysis, from the first contact with the paper to the end of the writing. Another observation made is that these criteria are more complex to use in graphometry, which requires great expertise on the part of the professional to make visual analyses.

Since the participants were invited to examine signature images on a website, the digital images did not enable other analyses, which made some criteria unfeasible and/or impossible to be observed or compared. Nonetheless, a statistical study was made to identify the importance and relevance of these findings to expert analysis.
In the univariate investigation, shown in Table 2, morphology was the only statistically significant criterion, showing that the evaluators who identified morphology as relevant were four times as likely to have a correct analysis as those who did not consider it so $(p$-value $=0.05)$.

Morphology is the form of writing, the most noticeable characteristic ${ }^{8}$. When analyzing morphology, the experts observe the handwriting - e.g., whether they are cursive or block letters. Hence, it cannot be used as an element to identify the handwriting, but it is necessary to make analysis possible. A cursive signature would be more successfully identified in an analysis that compared it to another pattern of cursive writing. This rationale is used for the other handwriting morphological patterns, as well.

Some criteria were promising for the multivariate analysis, with the following values for each one ( $p$-value $<0.20)$ : initial pen stroke $(\mathrm{OR}=2.4$; $p$-value $=0.08)$; inclination $(\mathrm{OR}=1.93$; $\mathrm{p}$-value $=0.11)$; dynamism or evolution $(\mathrm{OR}=1.78$; $\mathrm{p}$-value $=0.15)$.

Concerning the multivariate modeling of the criteria above, no variable obtained a $p$-value $<0.05$. This may indicate that some other aspect was not observed to explain multifactorially the evaluator's correct analysis (Table 3). 
Table 2. Univariate analysis to identify the variables most related to the evaluators' correct analyses

\begin{tabular}{|c|c|c|c|c|c|c|c|c|c|}
\hline \multirow{5}{*}{$\begin{array}{l}\text { VARIABLE } \\
\text { Time to vote }\end{array}$} & \multirow{5}{*}{$\begin{array}{c}\text { CATEGORIES } \\
\text { Less than } 30 \text { min. } \\
30 \text { or more min. }\end{array}$} & \multicolumn{4}{|c|}{ CORRECT ANALYSIS } & \multirow{2}{*}{\multicolumn{4}{|c|}{ ODDS RATIO* }} \\
\hline & & \multicolumn{2}{|c|}{$\mathrm{NO}(\mathrm{N}=54)$} & \multicolumn{2}{|c|}{ YES (N=97) } & & & & \\
\hline & & \multirow{3}{*}{$\begin{array}{c}\mathbf{N} \\
53 \\
1\end{array}$} & \multirow{3}{*}{$\begin{array}{c}\% \\
98.1 \\
1.9\end{array}$} & \multirow{3}{*}{$\begin{array}{c}\mathbf{N} \\
92 \\
5\end{array}$} & \multirow{3}{*}{$\begin{array}{c}\% \\
94.8 \\
5.2\end{array}$} & \multirow{3}{*}{$\begin{array}{c}\text { ESTIMATE } \\
1.00 \\
3.95\end{array}$} & \multicolumn{2}{|c|}{$95 \% \mathrm{Cl}$} & \multirow[t]{2}{*}{$p$-value } \\
\hline & & & & & & & & \\
\hline & & & & & & & 0.39 & 39.81 & \multirow{2}{*}{0.24} \\
\hline & No & 13 & 24.1 & 32 & 33.0 & 1.00 & & & \\
\hline Writing progress & Yes & 41 & 75.9 & 65 & 67.0 & 0.75 & 0.32 & 1.76 & 0.51 \\
\hline & No & 30 & 55.6 & 44 & 45.4 & 1.00 & & & \\
\hline Connections & Yes & 24 & 44.4 & 53 & 54.6 & 1.10 & 0.42 & 2.88 & 0.85 \\
\hline & No & 15 & 27.8 & 18 & 18.6 & 1.00 & & & \\
\hline Initial pen stroke & Yes & 39 & 72.2 & 79 & 81.4 & 2.40 & 0.89 & 6.51 & 0.08 \\
\hline & No & 17 & 31.5 & 27 & 27.8 & 1.00 & & & \\
\hline Final pen stroke & Yes & 37 & 68.5 & 70 & 72.2 & 1.37 & 0.55 & 3.41 & 0.51 \\
\hline & No & 40 & 74.1 & 72 & 74.2 & 1.00 & & & \\
\hline Positioning & Yes & 14 & 25.9 & 25 & 25.8 & 1.20 & 0.43 & 3.33 & 0.73 \\
\hline & No & 37 & 68.5 & 62 & 63.9 & 1.00 & & & \\
\hline Allgnment & Yes & 17 & 31.5 & 35 & 36.1 & 1.41 & 0.57 & 3.48 & 0.46 \\
\hline & No & 26 & 48.1 & 46 & 47.4 & 1.00 & & & \\
\hline Angular values & Yes & 28 & 51.9 & 51 & 52.6 & 1.67 & 0.68 & 4.10 & 0.27 \\
\hline Curvilinear values & No & 31 & 57.4 & 47 & 48.5 & 1.00 & & & \\
\hline Curvilinear values & Yes & 23 & 42.6 & 50 & 51.5 & 1.61 & 0.72 & 3.60 & 0.25 \\
\hline & No & 43 & 79.6 & 76 & 78.4 & 1.00 & & & \\
\hline Allographs & Yes & 11 & 20.4 & 21 & 21.6 & 2.68 & 0.43 & 16.78 & 0.29 \\
\hline & No & 36 & 66.7 & 62 & 63.9 & 1.00 & & & \\
\hline Construction method & Yes & 18 & 33.3 & 35 & 36.1 & 1.61 & 0.62 & 4.20 & 0.33 \\
\hline & No & 48 & 88.9 & 88 & 90.7 & 1.00 & & & \\
\hline Diacritics and punctuation & Yes & 6 & 11.1 & 9 & 9.3 & 1.14 & 0.36 & 3.64 & 0.83 \\
\hline & No & 33 & 61.1 & 52 & 53.6 & 1.00 & & & \\
\hline Inclination & Yes & 21 & 38.9 & 45 & 46.4 & 1.93 & 0.86 & 4.35 & 0.11 \\
\hline & No & 33 & 61.1 & 47 & 48.5 & 1.00 & & & \\
\hline Dynamism or evolution & Yes & 21 & 38.9 & 50 & 51.5 & 1.78 & 0.81 & 3.89 & 0.15 \\
\hline & No & 35 & 64.8 & 64 & 66.0 & 1.00 & & & \\
\hline Pressure & Yes & 19 & 35.2 & 33 & 34.0 & 0.86 & 0.31 & 2.37 & 0.77 \\
\hline & No & 34 & 63.0 & 59 & 60.8 & 1.00 & & & \\
\hline Writing rhythm & Yes & 20 & 37.0 & 38 & 39.2 & 0.88 & 0.36 & 2.15 & 0.78 \\
\hline & No & 50 & 92.6 & 89 & 91.8 & 1.00 & & & \\
\hline Line behavior & Yes & 4 & 7.4 & 8 & 8.2 & 1.70 & 0.45 & 6.38 & 0.43 \\
\hline & No & 46 & 85.2 & 79 & 81.4 & 1.00 & & & \\
\hline Base behavior & Yes & 8 & 14.8 & 18 & 18.6 & 1.82 & 0.64 & 5.18 & 0.26 \\
\hline Dearee of ckill & No & 40 & 74.1 & 69 & 71.1 & 1.00 & & & \\
\hline Uegree of SkIII & Yes & 14 & 25.9 & 28 & 28.9 & 1.59 & 0.61 & 4.18 & 0.34 \\
\hline & No & 28 & 51.9 & 60 & 61.9 & 1.00 & & & \\
\hline Pulse tendency & Yes & 26 & 48.1 & 37 & 38.1 & 0.94 & 0.38 & 2.36 & 0.90 \\
\hline & No & 33 & 61.1 & 64 & 66.0 & 1.00 & & & \\
\hline Writing moments & Yes & 21 & 38.9 & 33 & 34.0 & 1.05 & 0.47 & 2.36 & 0.90 \\
\hline Variability & No & 46 & 85.2 & 83 & 85.6 & 1.00 & & & \\
\hline Varıability & Yes & 8 & 14.8 & 14 & 14.4 & 0.93 & 0.32 & 2.71 & 0.90 \\
\hline & No & 29 & 53.7 & 53 & 54.6 & 1.00 & & & \\
\hline Speed & Yes & 25 & 46.3 & 44 & 45.4 & 0.91 & 0.37 & 2.20 & 0.83 \\
\hline Snacings & No & 33 & 61.1 & 62 & 63.9 & 1.00 & & & \\
\hline Spacings & Yes & 21 & 38.9 & 35 & 36.1 & 0.81 & 0.32 & 2.07 & 0.66 \\
\hline Veral limiting linec & No & 48 & 88.9 & 92 & 94.8 & 1.00 & & & \\
\hline Verbal IIIIIting IIInes & Yes & 6 & 11.1 & 5 & 5.2 & 0.00 & - & - & - \\
\hline & No & 31 & 57.4 & 62 & 63.9 & 1.00 & & & \\
\hline Calliber and proportions & Yes & 23 & 42.6 & 35 & 36.1 & 1.16 & 0.48 & 2.82 & 0.75 \\
\hline & No & 42 & 77.8 & 70 & 72.2 & 1.00 & & & \\
\hline Mlorphology & Yes & 12 & 22.2 & 27 & 27.8 & 3.99 & 1.00 & 15.94 & 0.05 \\
\hline Nature & No & 41 & 75.9 & 78 & 80.4 & 1.00 & & & \\
\hline Nature & Yes & 13 & 24.1 & 19 & 19.6 & 1.24 & 0.27 & 5.69 & 0.78 \\
\hline
\end{tabular}

Captions: $\mathrm{Cl}=95 \%$ / $\mathrm{p}$-value $=0.05 . \mathrm{Cl}=$ confidence interval

${ }^{*}$ Odds ratio estimated with the conditional logistic regression model 
Table 3. Conditional multivariate logistic regression model to identify the variables most related with the evaluators' correct analyses

\begin{tabular}{lcccc}
\hline VARIABLE & COEFFICIENT & ODDS RATIO & 95\% CI & P-VALUE \\
\hline Initial pen stroke $=$ Yes & 0.82 & 2.27 & 0.81 & 6.40 \\
Inclination $=$ Yes & 0.59 & 1.80 & 0.77 & 4.20 \\
Dynamism or evolution $=$ Yes & 0.50 & 1.64 & 0.72 & 3.74 \\
Morphology = Yes & 1.23 & 3.41 & 0.81 & 14.31 \\
\hline
\end{tabular}

Captions: $\mathrm{Cl}=95 \%$ / $p$-value $=0.05 \mathrm{Cl}=$ confidence interval

\section{DISCUSSION}

Asking the experts to analyze digital signature images instead of physical ones (in paper) may have hindered the inclusion of participants. Some of them contacted the researcher to say they did not feel confident to make this type of analysis and that they only worked with physical documents, not digital ones. The selection and exclusion of criteria the experts used and informed (e.g., handwriting pressure and evolution) may also have caused greater difficulties in digital analysis, whereas the criteria they reported as most used (initial and final pen stroke and handwriting progress) are more confidently observed in this type of analysis.

Graphometry aims for objective results and determinant criteria in the analysis, whereas the expert's perception regarding the selection of these criteria is subjective. Such subjectivity is related to each expert's practice and technical knowledge in relation to the cases presented to them (i.e., the signatures they must analyze). Another relevant observation in this regard is that graphometry may lack techniques aligned with digital media to improve the analysis process.

These findings greatly contribute to the current and future challenges posed by expert digital handwriting analysis, especially regarding speech-languagehearing pathologists who work or are interested in working as such expert analysts. This study shows the importance of the experts' technical and insightful knowledge when selecting and analyzing criteria. Thus, they can reach true conclusions in their analysis report, which is essential to a court's decision.

Further research can study a statistical score method to try and assess the subjectivity in choosing these criteria used in the expert signature analysis.

\section{CONCLUSION}

The most frequently used handwriting analysis criteria among experts (namely, initial and final pen stroke and handwriting progress) were not statistically relevant to a correct judgment. Also, the experts' subjectivity and expertise in choosing criteria were present when they turned in an expert analysis report, helping in court decisions.

\section{ACKNOWLEDGMENTS}

This study was financed in part by the Coordenação de Aperfeiçoamento de Pessoal de Nível Superior Brasil (CAPES) - Finance Code 001.

\section{REFERENCES}

1. Falat LRF, Rebello Filho HM. Entendendo o laudo pericial grafotécnico \& a grafoscopia. 1a ed. Curitiba: Juruá; 2012.

2. Feuerharmel S. Análise grafoscópica de assinaturas. 1a ed. Campinas, SP: Millenium; 2017.

3. Valiatia SL, Velho JA, Bruni AT. Investigation of individual characteristics in handwriting of a Brazilian Amazonian group. Brazilian Journal of Forensic Sciences, Medical Law and Bioethics [journal on the Internet]. 2016 [accessed 2021 Jun 14]; 5(2): [about 4 p.]. Available at: http://www. ipebj.com.br/forensicjournal/edicoes?volume $=5 \&$ numero $=2 \&$ artigo $=194$ \&lang $=$ ingles

4. Del Picchia FJ, Del Picchia CMR, Del Picchia AMG. Tratado de documentoscopia: da falsidade documental. 2nd ed. São Paulo: Editora Pilares; 2005.

5. Mendes LB. Documentoscopia. 3rd ed. Campinas, SP: Millennium Editora; 2010.

6. Gorziza RP. Estudo das características gráficas mais frequentes alteradas em disfarce de assinaturas. Revista Brasileira de Criminalística [journal on the Internet]. 2017 [accessed 2018 jul 20]; 6(1): [about 9 p.]. Available at: http://www.rbc. org.br/ojs/index.php/rbc/article/view/146/pdf

7. Bandeira JRR. A perícia grafotécnica nos tribunais brasileiros. Revista Âmbito Jurídico [journal on the Internet]. 2006 [accessed 2018 
jul 20]; 27 [aproximadamente 14 p.]. Available at: http://www.ambitojuridico.com.br/site/index. php?n_link=revista_artigos_leitura\&artigo_id $=1009$

8. Brasil. Lei № 13.105, de 16 de março de 2015 que dispõe sobre normas fundamentais e da aplicação das normas processuais. [accessed on 2020 dez 22]. Available at: http://www.planalto.gov.br/ ccivil_03/_ato2015-2018/2015/lei/13105.htm

9. Conselho Federal de Fonoaudiologia. Resolução no 584 Dispõe sobre a criação da especialidade em perícia fonoaudiológica, define as atribuições e competências relativas ao profissional fonoaudiólogo especialista, e dá outras providências. [accessed on 2020 dez 22]. Available at: https://www.fonoaudiologia.org.br/resolucoes/ resolucoes_html/CFFa_N_584_20.htm

10. Ferrer MA, Diaz-Cabrera M, Morales A. Static signature synthesis: a neuromotor inspired approach for biometrics. IEEE Transactions on Pattern Analysis and Machine Intelligence. [journal on the Internet]. 2015 [accessed 2020 dez 22]; 37(3): [about 13 p.]. Available at: https:// ieeexplore-ieee-org.ez15.periodicos.capes.gov.br/ document/6867369

11. Falat LRF. Produção da prova pericial grafotécnica no processo civil. 1a ed. Curitiba: Juruá; 2008.

12. Silva ESC, Feuerbarmel S. Documentoscopia: aspectos científicos, técnicos e jurídicos. Campinas, SP: Millennium; 2013.

13. Mendes LB. Documentoscopia. $3^{\mathrm{a}}$ ed. Campinas, SP: Millenniun; 2015.

14. Paula GA. Modelos de regressão: com apoio computacional [monography]. São Paulo (SP): Instituto de Matemática e Estatistica da Universidade de São Paulo - IME/USP; 2004. 


\section{APPENDIX 1}

\section{DEVELOPING A TOOL TO GATHER DATA FROM THE EXPERTS' ANALYSES}

\begin{tabular}{|llll}
\hline \multicolumn{1}{l}{ Home page } & & \\
\hline Research | Postgraduation & Log in & Register \\
\hline
\end{tabular}

\section{Welcome!}

To contribute to this research, you must make a handwriting analysis of the images of signatures shown on the screen. You must use the handwriting analysis criteria according to the information provided on the page that will appear after you register or log in. On the same page, you will inform whether the pair of signatures shown there is from the same handwriting, checking either YES (if they are from the same hand) or NO (if they are from different hands) In the sequence, you will choose from a list of criteria which ones you used in your analysis (you must choose at least five) and click "send".

Smartphone user: Click on to log in or register.

Computer user: Click on "log in" or "register" at the top of the page.

\section{Registry of the Expert Handwriting Analysts}

\begin{tabular}{|c|c|}
\hline \multicolumn{2}{|l|}{ Register } \\
\hline \multicolumn{2}{|l|}{ Full name } \\
\hline \multirow[b]{2}{*}{ State where you live } & \\
\hline & $\mathbf{v}$ \\
\hline \multirow{2}{*}{$\begin{array}{r}\text { Do you work in a } \\
\text { different state from } \\
\text { where you live? }\end{array}$} & ONo OYes \\
\hline & E.g., PE, PB, AL... \\
\hline Age & E.g., 35 \\
\hline Sex & O Female $\bigcirc$ Male \\
\hline $\begin{array}{r}\text { Educational Level } \\
\text { (choose the highest } \\
\text { one that applies to } \\
\text { you) }\end{array}$ & $\begin{array}{l}\text { Bachelor's degree O Specialization } \\
\text { O Master's degree O Doctoral degree }\end{array}$ \\
\hline $\begin{array}{r}\text { Have you studied any } \\
\text { higher education sub- } \\
\text { ject on expert hand- } \\
\text { writing analysis? }\end{array}$ & OYes ONo \\
\hline $\begin{array}{r}\text { Do you think it is im- } \\
\text { portant to make this } \\
\text { approach available in } \\
\text { undergraduate pro- } \\
\text { grams? }\end{array}$ & OYes ONo \\
\hline
\end{tabular}

What have you majored in?

What do you work with?

E.g., Computer Engineering O Forensic document examination Both

How long have you worked $\bigcirc$ Less than 3 years $\bigcirc 4$ to 5 years with expert handwriting $\bigcirc 6$ to 10 years $\bigcirc$ More than 10 years analysis?

In what area do you work? O Official expert $\bigcirc$ Extraofficial expert Official and extraofficial expert

Professional experience $\bigcirc$ Civil servant $\bigcirc$ Private service C Civil servant and private service

$$
\text { Password Use at least } 6 \text { characters }
$$

Confirm password Type in your password again

\section{Register}




\section{APPENDIX 2}

\section{Agreeing to the terms and beginning analyses}

\section{Important information}

The objective of this research is to study the criteria and procedures used in expert handwriting analysis. This research involves students and researchers from the postgraduate programs in Forensic Analysis and Computer Engineering at the University of Pernambuco.

NOTE: The analyses do not need to be made all at once. You can log in and out with the same user's name and password as many times as necessary.

\section{(1) Consent Form and Confidentiality Agreement}

\section{$\square$ I agree to the terms}

The assessment criteria to perform the handwriting analyses in this research are based on the following literature:

[FALAT, 2012]

[SILVA AND FEUERHARMEL, 2013]

[MENDES, 2015]

$\rightarrow$ Begin analyses 


\section{APPENDIX 3}

Comparison of signatures (the system made the 10 most voted signatures up to the time of registration available for the user to make the analyses)

Database used: GPDS 200

Signature 1:

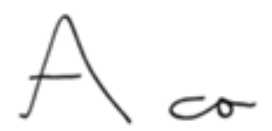

Signature 2:

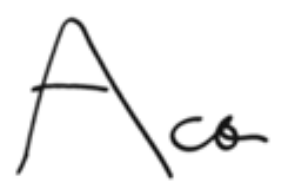

Criteria used in the analysis

Was the signature produced by the same handwriting?

Yes

No

Check the criteria you used in your analysis: Check at least 5 (five) criteria

\section{Connections}

Writing progress

Initial pen stroke

Final pen stroke

Positioning

Alignment

Angular values

Curvilinear values

Allographs

Construction method

Diacritics and punctuation

Inclination

Dynamism or evolution

Pressure

\author{
Writing rhythm \\ Line behavior \\ Base behavior \\ Degree of skill \\ Pulse tendency \\ Writing moments \\ Variability \\ Speed \\ Spacings \\ Verbal limiting lines \\ Caliber and proportions \\ Morphology \\ Nature
}

